\title{
Adaptation, learning, Bildung: Discussion with edu- and biosemiotics
}

\author{
Eetu Pikkarainen \\ Faculty of Education \\ University of Oulu \\ Oulu, Finland \\ e-mail: eetu.pikkarainen@oulu.fi
}

\begin{abstract}
Learning and adaptation are central problems to both edusemiotics, or semiotics of education, and biosemiotics. Bildung, as an especially human way or form of learning, and evolution as the main form of adaptation for many biologists after Darwin are often regarded as mutually exclusive concepts even though human beings are undeniably one biological species among others. In this article I will try to build a bridge between the biosemiotical, edusemiotical and Bildung-theoretical stances. Central to this discussion is biosemiotician Kalevi Kull and some of his recent publications where he considers adaptation, evolution and learning. The primary theoretical resource that I utilize here, in addition to the general Greimassian, edusemiotical and Bildungtheoretical starting points, is perceptual control theory (PCT) to which I compare the Uexküllian conception of functional circle.
\end{abstract}

Keywords: learning; Bildung; action; adaptation; Perceptual Control Theory (PCT); edusemiotics; biosemiotics

\section{Introduction}

In this article I study the connections between the concepts of learning and adaptation on the one hand and the connections between Bildung ${ }^{1}$ and evolution on the other. Learning and adaptation are central problems to both edusemiotics, or semiotics of education, and biosemiotics. Bildung, as an especially human way or

\footnotetext{
1 'Bildung' is an old German catch-word, which refers both to individual human - mostly mental - growth and to the development of human culture. It is sometimes translated as e.g. formation or culture, but all these alternatives are problematically narrow and confusing. See more at the end of this article.
} 
form of learning, and evolution as the main form of adaptation for many biologists, especially after Darwin, are often regarded as mutually exclusive concepts - this, despite the undeniable fact that human beings are just one biological species among others. It may first seem that what is at stake here is a dualism or conflict between two kinds of world views: on the one hand, a humanistic or anthropocentric one; on the other, a naturalistic or biological one. However, I will attempt to find a common point to these poles of the concept. Concepts of learning, adaptation and evolution all have a very wide use in different contexts: from animals to humans and even to machines and material and social systems. By contrast, Bildung is not very often used outside its original contexts in human culture and human learning. The aim of this study is to search for the common ground between edusemiotics and biosemiotics, the core of semiotics. As applied and developed in many areas of life, semiotics will naturally have many different meanings: there will, therefore, be this or that semiotics and a semiotics of this and that. However, for 'semiotics' to have any meaning at all, there must be a common basis for all those different branches. In this article I will try to build a bridge between the biosemiotical, edusemiotical and Bildung-theoretical stances.

Despite having no expertise in biology, I shall venture to discuss in the following some statements made by one of the most remarkable developers of biosemiotics, Kalevi Kull (see Lindström et al. 2012). Kull's insights are remarkably similar to my own views, which I have developed under the rubric of action-theoretical semiotics. However, the action-theoretical semiotics I have developed is based on Greimas, whereas Kull, like many biosemioticians, relies more on Peirce. The most important common starting point for both theoretical approaches is the circular model of action, originally developed by Jakob von Uexküll at the beginning of the 20th century (see Uexküll 1982). There are, however, some notable differences in the interpretation of that model. I will claim that the internal dynamics of this circle can be understood best through Perceptual Control Theory, developed by William T. Powers (2005[1973]). For Kull, and many others like myself until just a couple of years ago, the basic dynamic character which explains why some system acts circularly has remained quite fuzzy or even mystical. It must be stressed that I will not try to provide any systematic review of Kull's works but will only pick some recent publications in which he considers adaptation, evolution and learning.

\section{Adaptation and adaptiveness}

If we look at learning and adaptation from the point of view of action theoretical semiotics, the first fundamental dichotomy that comes to mind - and perhaps 
should come to mind - is between being and doing (Greimas, Courtés 1982). We are not so much interested in the "passive" objects of our environment but rather in the active subjects - the kind we think we are ourselves. This, I believe, is one common starting point in edusemiotics and biosemiotics: living beings are entities which are subjects in the strong, common sense meaning. That means that they are subjects of both being and doing, whereas objects are only subjects of being. Objects are passive entities. They are just what they are and can be affected by their environment, but they cannot actively affect anything. Of course, this dualism is leaky like most others. Objects have their own way of being, a habit if you will, and their properties are powerful (Heil 2012) enough to, in certain circumstances, affect other objects. They are also selectively sensitive to the influences of other objects or subjects so that the consequences of those influences to the way of being of a patient object depend also on its current way of being. In this way, objects are also (at least pre- or proto-) semiotical beings (see Pikkarainen 2013, 2016).

For now, we are more interested in the ways of being and doing of active, living subjects. It is just their ways of being and doing which are changed via learning and adaptation. In its everyday use, the term 'adaptation' has (at least in Finnish) a somewhat fatalistic flavour. It means that usually some subject becomes adapted to its conditions. This meaning probably derives from biology. Originally, the term 'adapt/adaptation' seems to have been more active, coming into English from French 'adapter', and into French from the Latin 'adaptare' - 'to' + 'fit'. It was used in the sense of a subject adapting an object to some use or need. But, since Darwin, it has been used in the passive voice: a subject (or species or system) becomes adapted to some situation or conditions. In biology adaptation has now two uses: either it is a process in which an organism or species becomes better suited to its environment, or it is the result of such a process. If in an adaptation process the organism acquires a new way of action or a new organ, these new ways or new organs are called adaptations (Kull 2014).

In biology, the concept of adaptation is usually connected to the concepts of evolution, natural selection and fitness. Evolution refers to hereditary changes in a species of organism. The inheritable changes from one generation to another can be caused by mutations or other random genetic alterations. Some changes will remain as features of the members of new generations and others will not, because the parents with $x$ features have more children and the parents with $y$ features have fewer children. This effect is called natural selection: some features are selected to continue, while others will vanish. Fitness is the quantitative measure of just that

2 Adapt. In: English Oxford Living Dictionaries. Oxford: Oxford University Press; retrieved from https://en.oxforddictionaries.com/definition/adapt. 
ability to reproduce affectively and thus make one's own features general. If fitness must be measured intragenerationally, the growth rate can be used (Sznajder et al. 2012: 308). It is clear that these concepts are not entirely suitable if we study edusemiotics and human learning, because then, for example, those groups of humans who reproduce rapidly - some sects and people in underdeveloped countries, on the one hand, or overweight people of rich western countries, on the other - should be regarded as the fittest and best adapted.

Kull stresses that instead of, or in addition to, the quantitative measure of fitness, a qualitative criterion of adaptation is needed. This criterion is needed in biology to differentiate between adaptive and neutral evolution. The criterion is that adaptation - in the original etymological meaning - that makes something suitable for a use, or is adjusted to something. That being so, a change is "adaptive if it solves some problem a living being faces" (Kull 2014: 287). In a similar way, we could talk about adaptive and neutral learning. The difference between learning and evolution is that the former means an ontogenetic change which is not inheritable, and which is thus reversible in future generations. Neutral changes are those which are not adaptive, i.e. they do not solve any problems of those beings in whom the changes take place.

At this point we can make some classifications. First, adaptation can be either active or passive. In the former case the subject solves some problem by adapting something in its environment, for example it can turn down an obstacle, find a tool to make something, kill an enemy or eat a prey. All these are adaptive changes, not in the subject, but rather in the environment ${ }^{3}$ and caused by the subject. In this sense we can say that the normal more or less successful action of the subject is adaptation or adaptive. In the latter case the subject itself changes. This could be a physical change such as the subject's growth in size, or growth of a new organ, or becoming more resistant, etc. If falling objects hurt the subject, then the growth of a more resistant upper skin will be adaptive, and, if getting fruit from a tree is difficult, then the growth of the subject's height is adaptive. On the other hand, the change could happen in the ways in which the subject acts. It can start to avoid an obstacle, use a tool in a new way, make friends with an enemy, or change its diet. These kinds of changes are called 'learning' and they will be considered in more detail below.

3 Here it must be remembered that the subject is in, and part of, its own environment. For example, moving where the subject causes immediate changes in its own position, and thus mediated changes in the relationships of its environment, is active adaptation. Only the changes in the subject which cannot be immediately caused by itself should be counted as passive. 
Here we should look at one special character of adaptive learning. It is a form of passive adaptation; but unlike the physical passive adaptation there is nothing adaptive in it as such. It is adaptive only and as much as it affects the way of action, i.e. the subject's active adaptation of its environment. That is why it is necessary to study action before learning and learning only in the context of action.

\section{Circular model of action}

The Urvater of biosemiotics and theoretical biology Jakob von Uexküll (18641944) wanted to develop a biology which is based on the purposefulness of organisms instead of (or, rather, in addition to) their physiology, which uses only causal relations. He developed two extremely important and influential - and interconnected - concepts: the functional circle 4 and the umwelt. He started to develop his concept of the functional circle already in the first decades of the 20th century (Kull 2001). Its most mature form appeared in Bedeutungslehre, written in 1940 and translated and published in English in 1982 (Uexküll 1982: 32). The model (see Fig. 1) is somewhat modified here, but its information content is as it was in the original. It is flipped, as in a mirror image, to better evoke a new model, which will be considered below. In addition, some of the original terms are abbreviated. The diagram should be read so that, above, there is the Subject organism or Meaning-Receiver which has two kinds of organs: a Perceptual Organ (PO) and an Effector Organ (EO). These organs have Effector and Receptor parts which are in contact with some external Object. Below, there is the Object which has two parts just like the Subject: Effector is in contact with Effector Cue-Carrier (ECC) and Receptor is in contact with Perceptual Cue-Carrier (PCC). These two parts, or carriers, are connected together by the Objective Connecting Structure (OCS) and together they form the Object as Meaning-Carrier. In Uexküll's (1982: 31) own words: "Because every behaviour begins by creating a perceptual cue and ends by printing an effector cue on the same meaning-carrier, one may speak of a functional circle that connects the meaning-carrier with the subject".

The subject's umwelt, i.e. its subjective universe, is created by its functional circles. According to Uexküll there are four important functional circles for most organisms, namely, the functional circles of physical medium, food, enemy and sex (Uexküll 1982: 33). This means that there are at least those four kinds of meaning-

4 A terminological note: Uexküll's original term was 'Funktionskreis', which has been translated as 'functional circle' in Uexküll 1982. However, in the remarkable special issue of Semiotica in 2001, dedicated to Uexküll and containing more than 800 pages, the phrase 'functional cycle' appears. In PCT, the circular model of control is called 'loop'. 
carriers in every umwelt: physical objects (perhaps obstacles or possibilities for movement), prey or other food, predators or other enemies and possible mating partners. There is nothing meaningless in any umwelt. The subject's whole active life consists of its functional circles.

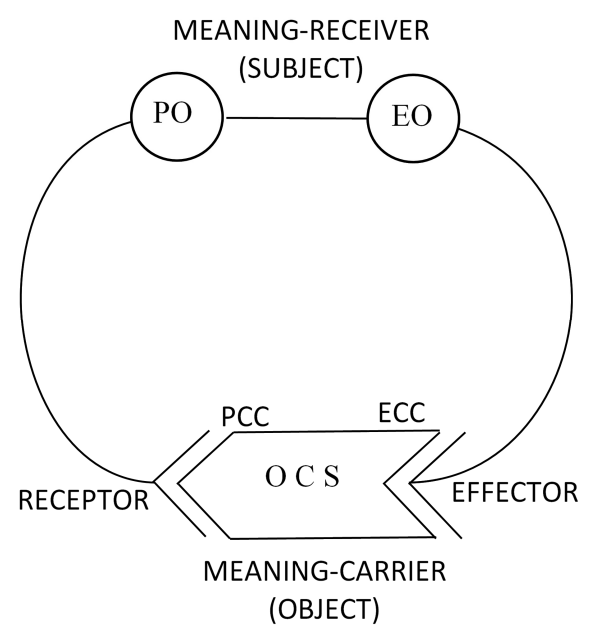

Figure 1. Model of the functional circle.

Instead of analysing the functional circle further, I would like to compare it with a somewhat more recent creation of William T. Powers (1926-2013), namely the perceptual control theory (PCT) (Powers et al. 1960; Powers 2005[1973]). Powers was not a biologist, but an engineer, and he built his theory from the very simple and much overlooked phenomenon of negative feedback. In the model of the negative feedback loop (see Fig. 2.) there are two poles: the subject (e.g. an organism or other system) and its environment. The subject can perceive something in its environment and it can also affect that something. Thus, the model's structure is very similar to that of the functional circle, but there is a striking difference. We could ask: why should the subject waste energy to affect that something in the environment which was perceived? For many, and especially for biologists, this question may perhaps sound trivial, and the answer is felt to be too self-evident to even be considered. Probably this is why it has not been explicated in the model of the functional circle. In fact, Uexküll sounds almost behaviouristic when he intimates that the perceptual cue just causes the effector to operate, even though the connection is not thought of as a physical causality, but rather as a 
musical induction, where one note leads to another note in a melody ${ }^{5}$. Note that in his model the perceptual and effector organs are connected by an empty line only, with no labels or explanations. However, Kull and Magnus have stated very clearly that the "circles of perception and action follow one another until the need that initiated them has been satisfied" (Kull, Magnus 2012: 651; my emphasis, E. P.).

It is exactly that need, or some similar state of affairs, that gets the subject to make an effort to affect the objects it perceives in its environment, which is modelled into the negative feedback loop and which separates PCT from other similar approaches. We do not act on all objects that we perceive but on a few only; and even those objects that we act on are not necessarily acted on continuously, but just occasionally. Hence the question: what causes that action - or rather, what causes the actual need that gets the subject to act? Here, PCT offers a simple solution, with two additional factors to the circular model (Powers 2005[1973]: 4447). The more important one is Reference, which is the internal goal or standard of the subject for some perception. Allowing a slightly metaphorical formulation, we could say that Reference is what the subject wants to perceive. In an ideal situation, the subject is in perfect harmony with its environment (in Heaven or nirvana) and perceives only what it wants to perceive. This harmony can be broken by one of two causes: either the subject's reference changes or the environment changes. That latter cause is called Disturbance.

The difference - called Error - between the perception and the reference is what causes the needs of the subject, and, consequently, the action - called Output which is directed to cancel the disturbance. The error is calculated using a simple subtraction in a part of the circle called Comparator. When, and only when, an error appears, either as a consequence of a reference change or a disturbance, or both, will the subject evince an actual need at which an output as action or behaviour is initiated. The output can consist of muscular movements or, in some cases, of secretion - or perhaps something else - and it will continue as long as the error prevails.

5 According to Jämsä (2001: 481), Uexküll was one of the first to see life as continuous process. 


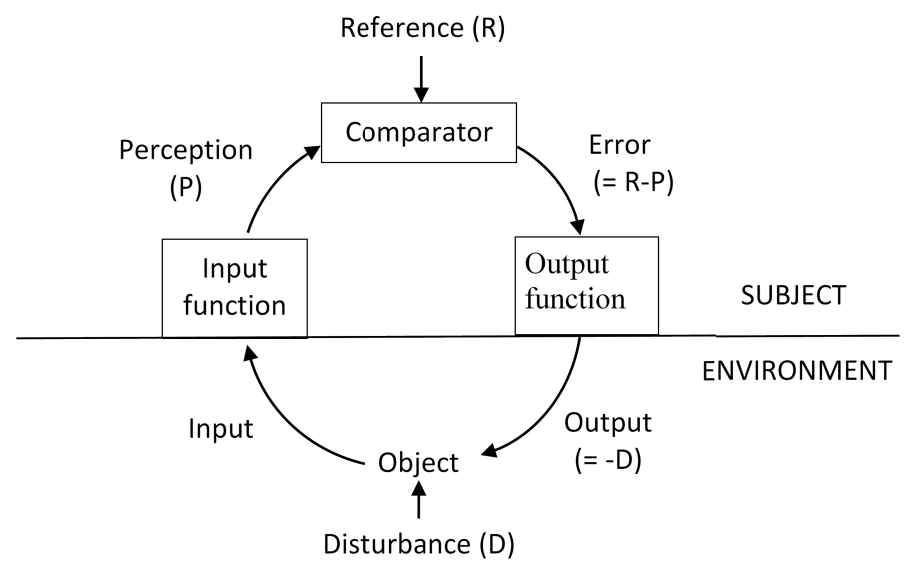

Figure 2. The model of the negative feedback loop.

Thus, the action of a subject is always in terms of control of perception i.e. bringing the perception near to the reference and keeping it there. What is important to notice is that if we study a complex organism, for instance an animal, it does not consist only of some parallel and alternative circles such as the object, the enemy, food and sex but still more importantly of a network of a multitude of hierarchically organized circles. The lowest circles take care of the relatively simple quantitative interactions with the environment. Higher circles combine and manage the perceptions of the lower ones and determine their references (Powers 2008: 127-144). In Uexküllian terms, the hierarchy of the elementary control circles form the Innenwelt of the organism which must somehow be similar to its umwelt. The lowest-level circles perceive only simple quantitative features such as intensities, distances, weights etc. but at the higher levels the conscious qualia and conceptual perceptions like objects, relations, events and principles are formed from these "raw data" (see Powers 1998: 27-43).

\section{The concept of learning}

In addition to the natural fact that the concept of learning is central to edusemiotics, it is also extremely important to biosemiotics. This is amply illustrated at two levels in Kull's writings. First, learning is a basic feature of all life: "Organic plasticity the ability to solve unexpected problems, to accommodate one's behaviour during the lifetime, according to circumstances - is a universal feature of all living beings" 
(Kull 2014: 288). Secondly, the phenomenon of learning is the basic starting-point for developing a biosemiotic or meaning-based alternative to the Neo-Darwinian theory of evolution. The idea behind this theory project is that evolution is not wholly, or perhaps not even essentially, driven by blind natural selection (of blind mutations), but instead it is driven by the meaningful learning of organisms in new situations. The random mutations and the meaningful mating behaviour then make these new learned behaviours genetically fixed and irreversibly inheritable (Kull 2014: 290-291). This means that learning and meaningful action is not made possible by evolution but, rather, the other way around: learning and meaningful action make evolution possible.

This view is extremely interesting, but here the concept of learning seems to be too general. First, if it is identified with organic, i.e. phenotypic, plasticity, which contains also those passive physical adaptations like becoming more durable or growing taller or, in an extreme case, growing a new organ. Secondly, the ability to solve problems and to accommodate one's behaviour according to circumstances does not necessarily mean, or require, learning. This is because action, as such, is always problem-solving and an accommodation of one's behaviour to circumstances. According to the PCT model of action, behaviour is always initiated by the problem that perception does not correspond to the subject's reference. The subject tries to solve this problem by accommodating its behaviour to circumstances so that the disturbance would be cancelled, and perception be drawn nearer to the reference. This is just the case of the subject's active adaptation and it is not the same thing as learning.

I have found it helpful to differentiate between learning and action using (in the Greimassian way) the concepts of competence and performance. Every active behaviour - be it empirically perceivable or not - is performance. Performances can be more or less skilful, and they always appear in a new way and form in new contexts. Performances as such, however, are not learning. Performances are made possible by the subject's special features, called competences. Competences are part of the way of being for the subject similarly as dispositions are for objects, and they assumedly exist in the subject also during the periods when they are not manifested in performance (cf. Martin 2002). Because action is always problemsolving, it will appear as different performances depending on the changing circumstances even though the competences remain the same and no learning is not required. Only the process of the changing of the subject's competences should be called learning (Pikkarainen 2014). This differentiation is not at all threatened by the possible, and even probable, matter of the fact that learning - the change of competences - will take place only as a consequence or side-effect of the subject's action - performances. 


\section{"Semiotic learning"}

In several of his publications, Kull has developed a very interesting view of a special semiotic form of learning, also explaining how learning happens (see esp. Kull 2015a). The concept of semiotic learning is based on, and interconnected with, a bunch of other central concepts, especially those of the phenomenal present, the logical conflict, semiosis and some others. It can be depicted negatively as differentiation from such non-living and non-semiotic phenomena like natural selection and machine learning. The idea is based on the general and traditional Uexküllian biosemiotical programme, which studies living beings from the point of view of meanings. Kull sharpens this view by stating that biosemiotics (and especially zoosemiotics) provides a phenomenological approach to the internal aspects of an organism's life - its umwelt. Here I again must compare this to PCT, where the aim is to find out what perceptions the subject is trying to control (Runkel 1990).

Kull ties the phenomenological approach to the concept of semiosis, which he identifies with interpretation (Kull 2015a: 144-145). In turn, interpretation requires two conditions: on the one hand, a logical conflict or an incompatibility of some options or choices; on the other, a phenomenological now or internal present as a subjective duration felt as one moment so that the options or choices, which computationally taken are always sequential, are seen simultaneously. During that internal present the options are not in any predetermined order and so the subject can in some way order them and choose between them freely. ${ }^{6}$ Thus, the choice must not be determined causally or probabilistically.

However, to be adaptive the choice should not be purely random either. Rather, it is based on semiotic scaffolding. This explains why a "principally free choice can often produce entirely predictable behaviours, if described by an outside observer" (Kull 2015b: 620). The concept of semiotic scaffolding was developed by, e.g., Jesper Hoffmeyer from the Neo-Vygotskian use of the term 'scaffolding'. It means, simply, that all semioses leave traces and thus form a scaffolding structure, which then supports and guides the subsequent semioses. In fact, it is precisely this that defines what semiotic learning is about.

Kull (2015b: 620) describes the process of semiotic learning in as follows: first the subject acquires rules (or habits); then in some situation a conflict occurs between these rules and, finally, the subject solves the conflict by choosing between the conflicting options. Here, some problems arise. The rule or habit is described

6 Here Kull seems to think that there cannot be other ordering principles between the options than the temporal sequence. Still, it feels very probable that there could be other kinds of weight differences between the options, which would determine their order, even if they were simultaneous. 
as an operation in the form: "IF a THEN DO b" (Kull 2015b: 617). This is a very rigid formulation, resembling closely the behaviouristic "laws", in which a certain external stimulus determines the subject's response. A living organism does not act in this way, because its doings are determined by its own goals rather than by external stimuli. Secondly, if the solution of the conflict is found by choosing from the conflicting rules, then no new rule will ever occur. At best, some of the existing rules become stronger than the others. Kull himself has stated this scheme also quite differently, naming the stages as 'incompatibility', 'innovation' and 'habituation' (Kull 2015a: 229). However, further in this text, Kull still writes only about choice.

In a PCT model there is no possibility of choosing - at least at the level of the individual control unit, even though there can be a conflict between perception and reference. Similarly, as conceived by Kull, these conflicting parties must exist simultaneously, but the subject does not choose between them: it only compares them and creates the error as a result of a subtraction operation. There is no choice for the subject: ${ }^{7}$ if it perceives something and if that perception does not correspond to its reference, then an output will necessarily ensue from the error, which tries to correct the situation by cancelling the disturbance. Although this might seem like an automatic reaction, it can still be regarded as free action because it is fully based on the subject's own self-determined goals. This is precisely the difference between living organisms and engineered machines: the former have their own innate and self-determined goals; whereas for the latter, the goals are externally determined by the building engineer or the user who sets the adjustments. Learning, in PCT, is assumed to take place as a reorganization of the parts of the hierarchical control network, the Innenwelt of the organism (Stables et al. 2018: 211-212).

It seems, therefore, that too much is required from semiosis and life - which in biosemiotics are generally understood as co-existing phenomena - from the assumption that in the internal present there should always be such conflicts and choice-making. Rather, it is sufficient that there are the innate and internal goals which the organism can strive for thanks to the negative feedback loop ${ }^{8}$. However, that conception of internal conflict solution through choice or innovation during the internal present sounds extremely useful for analysis of, primarily, humans no doubt animals, too - and their umwelten. In PCT, learning is modelled as a reorganization driven by errors in critical homeostatic variables or continuing

7 This could also be expressed so that a control system always "chooses" what it already thinks to be the best choice.

8 Powers (1995) has also studied how the beginning of life can be seen as the appearance of the first chemical compound which started to actively preserve itself. 
errors in normal control (Powers 1998: 46-57). The process of reorganization is guided by an evolution-like algorithm which is structurally similar to the method of movement guidance of the e-coli bacterium (Powers 2008: 107-112). However, in complex organisms this process is strongly affected by consciousness (Powers 2009) and here, naturally, pondering between different possibilities of action is a strong and central source of learning.

\section{From forms of learning to Bildung}

According to Kull there are four hypothetical forms of both learning and umwelten (Kull 2017: 147). The classification of the forms of learning is based on the main types of signs - and the forms of umwelten as based on respective forms of learning. The forms of learning are imprinting (iconic signs), conditioning (indexical signs), imitating (emonic signs) and conventioning (symbols). The first form means that the subject learns to attach a sign to something, or perhaps, rather, to recognize something as a sign of something. Here it is important that the iconic sign is not based on objective similarity, but rather the similarity which is created in the recognition. This is the form of learning which is possible, for example, in plants; and thus it is the basis for the first form of umwelten, namely vegetative ones. ${ }^{9}$ The second form of learning requires that the subject should connect two signs together. The nervous system is effective in making connections between separate signs and activities and so this form of learning is the basis for animal umwelten. The third form of learning is an interesting exception from Kull's otherwise quite purely Peircean system. By imitation, Kull refers to a sign relation where a subject links the exteroceptive and proprioceptive perceptions of some activity. This makes it possible to learn from the action of other subjects. Although this learning is connected to the social umwelt, it is not available to all social animals but only to vertebrates. The last form of learning requires the handling of most complex sign relations, namely symbols, because there the subject must intentionally combine and recombine different signs. This last form is clearly typical of humans only.

According to a model of modal learning which I developed (Stables et al. 2018: Ch. 15) based on the Greimassian conception of modalities, the modal competences of all (especially human) action are want, can, know and must (Greimas, Courtés 1982). Here, I will touch on the question of modalities only as far as necessary and instead concentrate on the structural similarity between the levels of learning in my model and in Kull's. The main difference with respect

9 Here we should note that Kull is more permissive than Uexküll, who restricted the concept of umwelt to animals. Plants had only dwelling-integuments, not umwelten. 
to Kull's model is that modal learning is about the development of the subject's competences of action - including both external bodily action and internal mental or thinking action - whereas Kull's semiotic learning seems to be most interested in the development of knowledge as the ability to use different kinds of signs. In the current model of modal learning there are three levels of learning - or rather of Bildung. I will return to this later. Here the differentiating principle between the levels is mainly the form of the modality of must. The first level is that of pragmatic learning. This somewhat connects the two first levels of Kull's model. In this level the must is in the form of an implicit or explicit technical norm: if you want A then you must do B (see von Wright, 1963). The second level is social learning where new forms of must develop as social norms on the one hand, and altruistic motives on the other. The third level is called existentialistic, because at this stage the individual conscience as abstract ethical principles and ways to compare them develop.

Traditionally, in Continental pedagogical thinking, the special human form of learning is referred to using the concept of Bildung. This German term has no proper English equivalent or translation and perhaps it will someday share the fate of the term 'umwelt'. However, given the theoretical and historical load of this term, it will probably take some time before that happens (see Siljander et al. 2012). The concept of Bildung has many sides (Pikkarainen 2016; 2017). First, it involves the human way of learning connected to culture and language. As such, it comes very close to Kull's learning as conventioning (cf. Brandom 2009; McDowell 1996). Secondly, it refers to the active development of culture and the ways of being of the entire humankind. Hence, it contains an active adaptation by action within itself. Thirdly, there is the question of the contents of Bildung: what competences should human beings learn, what knowledge, what skills, what attitudes, etc.? Thus, the Bildung concept has clearly a normative load to it which may make it strange to natural scientists but less so to biosemioticians (see e.g. Hoffmeyer 1995; Tønnessen et al. 2015). This normative content also means that Bildung is always connected to education as an intentional and institutional activity (Kontio et al. 2017).

Bildung as a human adaptivity should not be seen as only the perfection of human possibilities as it has been often traditionally thought of, but also human problem solving. Typical of problem solving in a dense ecosystem and, even more, in an overcrowded and technologically networked modern world is that it causes always many side-effects and possibly more and worse new problems than it solves. This phenomenon stresses a certain general type of goal or content of Bildung, namely a kind of respectfulness. In PCT discussion the concepts of arbitrary and respectful control are differentiated (Marken, Carey 2015: 97; Powers 2005[1973]: 271) in which the latter means that we take into consideration the side-effects of 
our actions to other subjects - and also to ourselves in the future. Kull's theoretical innovation of emonic learning as a general prerequisite of empathy could add useful tools to achieving this goal.

\section{Conclusions}

In this article I attempted to map and discuss some connections, and also some controversies in these connections, between my edusemiotic views and Kalevi Kull's respective biosemiotic theories. I have stated that the common Uexküllian circular model of action could be enriched and particularized by utilizing concepts and models of the Perceptual Control Theory. I have also suggested that the concept of learning could be analysed more fruitfully by using the concepts of competence and performance and defining it as a change or development of competences of the subject. That change, or development, could then be studied further as the reorganization of the subject's control hierarchy. This could then be combined easily with Kull's theory of the four forms or levels of learning and umwelten. Also, the types of signs and especially the idea of emonic signs should be utilized in the model of modal learning. The idea of internal present and conflict solution is probably most fruitfully applied with the phenomena of consciousness or at least awareness - or eusemiosis in the sense of Sharov (2012: 63).

Perhaps the most important finding of this study is the reinforcement of the view of a certain parallelism between the concept of Bildung and the concept of evolution. First, both are open-ended processes, leading continuously to something new. Already in 1858, Alfred R. Wallace, starting from a surprisingly explicit concept of negative feedback phenomenon, reasoned that nature has a tendency to create varieties and develop them further and further with no definite limits (Darwin, Wallace 1971). Kull adds here a remarkable semiotic twist by founding the creative development on meaningful action and problem solving of individual organisms and their communities. This brings evolution very close to the definition: "The term Bildung refers to process by which humanity produces humanity itself in individual action and coexistence" (Kivelä et al. 2012: 306).

\section{References}

Brandom, Robert 2009. Reason in Philosophy: Animating Ideas. Cambridge: Belknap Press of Harvard University Press.

Darwin, Charles; Wallace, Alfred Russel 1971. Evolution by Natural Selection. New York: Johnson Reprint Co. 
Greimas, Algirdas J.; Courtés, Joseph 1982. Semiotics and Language: An Analytical Dictionary. Bloomington: Indiana University Press.

Heil, John 2012. The Universe as We Find it. Oxford: Oxford University Press.

Hoffmeyer, Jesper 1995. Biosemiotics and ethics. In: Shiva, Vandana; Moser, Ingunn (eds.), Biopolitics: A Feminist and Ecological Reader on Biotechnology. London: Zed, 141-151.

Jämsä, Tuomo 2001. Jakob von Uexküll's theory of sign and meaning from a philosophical, semiotic, and linguistic point of view. Semiotica 143(1/4): 481-551.

Kivelä, Ari; Siljander, Pauli; Sutinen, Ari 2012. Between Bildung and growth - connections and controversies. In: Siljander, Pauli; Kivelä, Ari; Sutinen, Ari (eds.), Theories of Bildung and Growth: Connections and Controversies between Continental Educational Thinking and American Pragmatism. Rotterdam: Sense Publishers, 303-312.

Kontio, Kimmo; Pikkarainen, Eetu; Siljander, Pauli 2017. A modern idea of the school. In: Siljander, Pauli; Kontio, Kimmo; Pikkarainen, Eetu (eds.), Schools in Transition: Linking Past, Present, and Future in Educational Practice. Rotterdam: Sense Publishers, 97-112.

Kull, Kalevi 2001. Jakob von Uexküll: An introduction. Semiotica 134: 1-59.

- 2014. Adaptive evolution without natural selection. Biological Journal of the Linnean Society 112(2): 287-294.

- 2015a. Evolution, choice, and scaffolding: Semiosis is changing its own building. Biosemiotics $8(2): 223-234$.

- 2015b. Semiosis stems from logical incompatibility in organic nature: Why biophysics does not see meaning, while biosemiotics does. Progress in Biophysics and Molecular Biology 119(3): 616-621.

- 2017. On the logic of animal Umwelten: The animal subjective present, or zoosemiotics of choice and learning. In: Marrone, Gianfranco (ed.), Zoosemiotica 2.0: Forme e politiche dellanimalità. Palermo: Museo Pasqualino, 143-156.

Kull, Kalevi; Magnus, Riin 2012. Roots of culture in the Umwelt. In: Valsiner, Jaan (ed.), The Oxford Handbook of Culture and Psychology. Oxford: Oxford University Press, 649-661.

Lindström, Kati; Magnus, Riin; Maran, Timo; Tønnessen, Morten 2012. Kalevi Kull and the rewilding of biosemiotics: Introduction. In: Maran, Timo; Lindström, Kati; Magnus Riin; Tønnessen Morten (eds.), Semiotics in the Wild: Essays in Honour of Kalevi Kull on the Occasion of his 60th Birthday. Tartu: University of Tartu Press, 7-13.

Marken, Richard; Carey, Timothy 2015. Controlling People: The Paradoxical Nature of Being Human. Bowen Hills: Australian Academic Press.

Martin, Charles B. 2002. Properties and dispositions. In: Armstrong, David M.; Martin, Charles B.; Place Ullin T.; Crane, Tim (eds.), Dispositions: A Debate. London: Routledge, 71-87.

McDowell, John 1996. Mind and World: With a New Introduction. Cambridge, London: Harvard University Press.

Pikkarainen, Eetu 2013. From the ontology of interaction to the semiotics of education. In: Tirri, Kirsi; Kuusisto, Elina (eds.), Interaction in Educational Domains. Rotterdam: Sense Publishers, 51-62.

- 2014. Competence as a key concept of educational theory: A semiotic point of view. Journal of Philosophy of Education 48(4): 621-636.

- 2016. Signs as functions: Edusemiotic and ontological foundations for a semiotic concept of a sign. Semiotica 212: 27-44. 
- 2017. School learning as human growth: Modal dynamics of learning. In: Siljander, Pauli; Kontio, Kimmo; Pikkarainen, Eetu (eds.), Schools in Transition: Linking Past, Present, and Future in Educational Practice. Rotterdam: Sense Publishers, 97-112.

Powers, William T. 1995. The origins of purpose: The first metasystem transitions. World Futures 45(1-4): 125-137.

- 1998. Making Sense of Behavior: The Meaning of Control. Montclair: Benchmark Publications.

- 2005[1973]. Behavior: The Control of Perception. (2nd ed., revised and expanded.) New Canaan: Benchmark Publications.

- 2008. Living Control Systems III: The Fact of Control. Bloomfield: Benchmark Publications.

- 2009. PCT and MOL: A brief history of perceptual control theory and the method of levels. The Cognitive Behaviour Therapist 2(3): 118-122.

Powers, William T.; Clark, Robert K.; McFarland, Robert 1960. A general feedback theory of human behavior. In: Bertalanffy, Ludvig von; Rapoport, Anatol (eds.), General Systems: Yearbook of the Society for General Systems Research 5. Michigan: Society for General Systems Research, 63-83.

Runkel, Philip Julian 1990. Casting Nets and Testing Specimens: Two Grand Methods of Psychology. New York: Praeger.

Sharov, Aleksei 2012. The origin of mind. In: Maran, Timo; Lindström, Kati; Magnus, Riin; Tønnessen, Morten (eds.), Semiotics in the Wild: Essays in Honour of Kalevi Kull on the Occasion of his 60th Birthday. Tartu: University of Tartu Press, 46-70.

Siljander, Pauli; Kivelä, Ari; Sutinen, Ari (eds.) 2012. Theories of Bildung and Growth: Connections and Controversies between Continental Educational Thinking and American Pragmatism. Rotterdam: Sense Publishers.

Stables, Andrew; Nöth, Winfried; Olteanu, Alin; Pesce, Sébastien; Pikkarainen, Eetu 2018. Semiotic Theory of Learning: New Perspectives in the Philosophy of Education. Abingdon: Routledge.

Sznajder, Beata; Sabelis, Maurice W.; Egas, Martijn 2012. How adaptive learning affects evolution: Reviewing theory on the Baldwin effect. Evolutionary Biology 39(3): 301-310.

Tønnessen, Morten; Hendlin, Yogi; Beever, Jonathan (eds.) 2015. Zeitschrift fur Semiotik 37(34). [Special issue on biosemiotic ethics.]

Uexküll, Jakob von 1982. The theory of meaning. Semiotica 42(1): 25-82.

Wright, Georg Henrik von 1963. Norm and Action: A Logical Enquiry. Routledge, London.

\section{Адаптация, обучение, Bildung: дискуссия с семиотикой образования и биосемиотикой}

Обучение и адаптация являются центральными проблемами как семиотики образования, так и биосемиотики. Становление (Bildung) как исключительно человеческая форма обучения и эволюция как главная форма адаптации многими биологами после Дарвина часто рассматриваются как взаимоисключающие понятия. В этой статье я попытаюсь построить мост между позициями биосемиотики, семиотики образования (edusemiotical) и позициями Bildung-теории. В центре дискуссии недавние публикации биосемиотика Калеви Кулля, в которых он рассматривает адаптацию, эволюцию и обучение. Основной теоретический ресурс, которым я пользуюсь, в дополнении к теориям Греймаса, 
является теория перцептуального контроля, которая сопоставляется с концепцией функционального круга Юкскюлля.

\section{Adapteerumine, õppimine, Bildung: diskussioon haridus- ja biosemiootikaga}

Õppimine ja adapteerumine on nii haridussemiootika kui ka biosemiootika kesksed probleemid. Bildung kui inimomane õppimisviis ning evolutsioon kui paljude Darwini-järgsete bioloogide jaoks peamine võimalus adapteeruda on tihti esitatud teineteist välistavate mõistetena, kuigi inimeste näol on kahtlemata tegu ühe bioloogilise liigiga teiste seas. Käesolevas artiklis üritan omavahel ühendada biosemiootilisi, haridussemiootilisi ja Bildung-semiootilisi hoiakuid. Diskussiooni keskmes on mõned biosemiootik Kalevi Kulli hiljutised publikatsioonid, milles ta käsitleb adapteerumist, evolutsiooni ja õppimist. Esmane teoreetiline ressurss, mida siinkohal lisaks Greimasest lähtuvatele, haridussemiootilistele ja Bildung-semiootilistele lähtekohtadele kasutan, on tajukontrolli teooria (PCT), millega kõrvutan Uexkülli funktsiooniringi mõistet. 